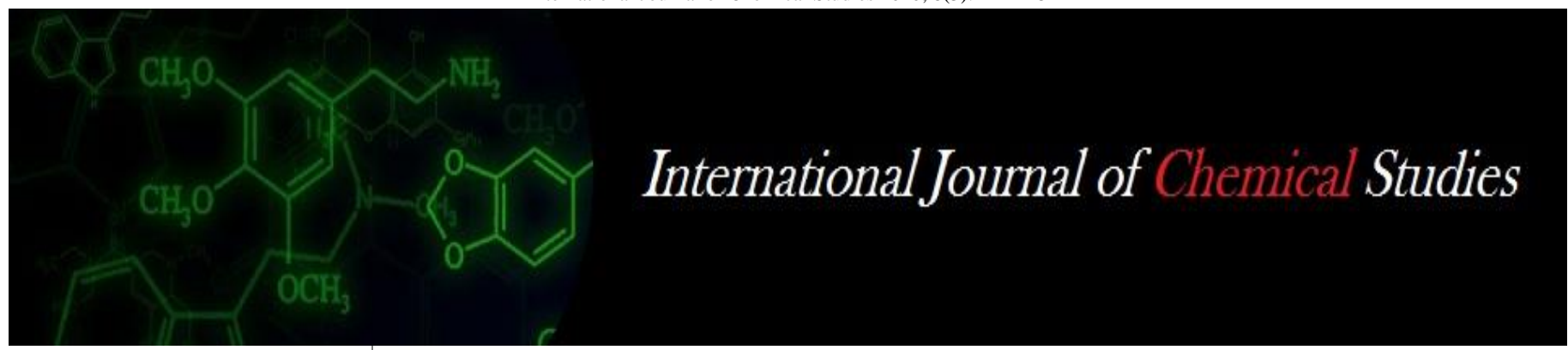

P-ISSN: 2349-8528

E-ISSN: 2321-4902

www.chemijournal.com

IJCS 2020; 8(3): 141-145

(C) 2020 IJCS

Received: 19-03-2020

Accepted: 21-04-2020

Bhagyashree Das

Department of Fruit Science and

Horticulture Technology, College

of Agriculture, OUAT,

Bhubaneswar, Odisha, India

Dilip Kumar Dash

Professor \& Head, Department

of Fruit Science and Horticulture

Technology, College of

Agriculture, OUAT,

Bhubaneswar, Odisha, India

Prabhat Chandra Pradhan

Precision Farming Development

Centre, OUAT, Bhubaneswar,

Odisha, India

Pragyanshree Priyadarshinee

Sahu

Department of Fruit Science and

Horticulture Technology, College

of Agriculture, OUAT,

Bhubaneswar, Odisha, India

Corresponding Author:

Bhagyashree Das

Department of Fruit Science and

Horticulture Technology, College

of Agriculture, OUAT,

Bhubaneswar, Odisha, India

\section{Influence of fertigation on Mrig Bahar guava (Psidium guajava L.) var. Arka Amulya under high density planting system}

\author{
Bhagyashree Das, Dilip Kumar Dash, Prabhat Chandra Pradhan and \\ Pragyanshree Priyadarshinee Sahu
}

DOI: https://doi.org/10.22271/chemi.2020.v8.i3b.9216

\begin{abstract}
A field experiment was carried out during 2018-19 at Precision Farming Development Centre, Bhubaneswar, Odisha to find out the effect of fertigation scheduling on vegetative and reproductive growth behaviour of guava var. Arka Amulya under eastern coastal plain zone of India. Three levels of fertilizer dose $(100 \%, 80 \%, 60 \%$ RDF) in combination with three levels of fertigation frequency (monthly, bimonthly, quarterly) and control as $100 \%$ RDF in soil application was evaluated employing Factorial Randomized Block Design and replicated thrice. The result of the investigation revealed that both the vegetative and reproductive characters were significantly influenced by use of different fertilizer dozes at different frequencies. Among the treatment combination $100 \%$ RDF at monthly interval resulted in maximum vegetative growth, viz. plant girth $(0.90 \mathrm{~cm})$, canopy volume $\left(7.79 \mathrm{~m}^{3}\right)$, leaf area $(50.42$ $\left.\mathrm{cm}^{2}\right)$, number of tertiary shoots $(58.25)$, tertiary shoot girth $(2.16 \mathrm{~cm})$ and number of leaves per tertiary shoots (18.00) while canopy volume, leaf area, girth of primary branch and tertiary shoot remain statistically at par with $80 \%$ RDF at monthly fertigation. Also the maximum tertiary shoot length $(16 \mathrm{~cm})$ was observed in $80 \%$ RDF at monthly interval. Similarly the reproductive characters like number of reproductive shoots (31.50), number of flowers (14.81), fruit set $(79.49 \%)$ and fruit retention $(45.60 \%)$ were highest in $80 \%$ RDF at monthly interval. Therefore, considering the positive effect on plant, $80 \%$ $\mathrm{RDF}$ at monthly interval is considered to be the best from economic point of view.
\end{abstract}

Keywords: Guava fertigation, water soluble fertilisers, frequency, RDF

\section{Introduction}

Guava (Psidium guajava L.), belongs to Myrtaceae family and is native to tropical America. It holds a pioneer position among all other major tropical fruits worldwide. In India it is claimed to be the fourth most important tropical fruit crops, after mango, banana and citrus. In India guava is grown on the area of 262 thousand hectare with an annual production of 3,648 thousand metric tonnes and a productivity of 13.9 metric tonnes/ha. In Odisha, it occupies an area of 14.22 thousand hectares with an annual production of 103.99 thousand metric tonnes (NHB-2016-17).

Mineral nutrition as a vital input plays an important role for increasing production, productivity and quality of fruits. It greatly influences the plant vigour, flower bud formation, fruit set and fruit drop, production and quality. Hence application of fertilizer solution directly through fertigation has the potential to ensure the right combination of water and nutrient is applied in controlled quantity, at right time to the root zone as per the requirements at different crop growth stages.

Fertigation is an advanced technique that has been followed but the fertigation schedules were followed arbitrarily by the growers due to lack of unavailability of scientifically worked out fertigation schedules. The fertilizers are to be applied in a schedule to cope with crop demand and split application from time to time can improves quality and quantity of any crop yield. Therefore, the present investigation was carried out to assess the effect fertigation schedule on vegetative and reproductive characters of guava var. Arka Amulya under high density planting system. 


\section{Materials and Methods}

The experiment was conducted at research field of Precision Farming Development Centre (PFDC), Horticultural Research Station, OUAT, Bhubaneswar, Odisha during the year 2018 to 2019. The experimental site is situated at an altitude of $52 \mathrm{~m}$ above mean sea level with latitude of $20^{\circ} 16^{\prime} 44^{\prime \prime} \mathrm{N}$ and longitude of $85^{\circ} 47^{\prime} 15^{\prime \prime} \mathrm{E}$. The area comes under east and south-eastern coastal plain zone of Odisha. The soil was texturally classified as sandy loam, having a pH of 4.7, EC of $0.07 \mathrm{dSm}^{-1}$ and organic content of $0.37 \%$. The experiment was laid out in Factorial randomized block design with ten treatments which are replicated thrice. There were 3 levels of fertilizer dose viz. $100 \%$ recommended dose of fertiliser (RDF) through fertigation $\left(\mathrm{F}_{1}\right), 80 \%$ RDF through fertigation $\left(\mathrm{F}_{2}\right), 60 \%$ RDF through fertigation $\left(\mathrm{F}_{3}\right)$ and 3 levels of fertigation frequency i.e., monthly interval $\left(\mathrm{S}_{1}\right)$, bimonthly interval $\left(S_{2}\right)$ and quarterly interval $\left(S_{3}\right)$. The $100 \%$ RDF in soil application was done in two split during the month of June-July and October-November. The details of treatment combinations are given below

Table 1: Treatment combinations along with symbols

\begin{tabular}{|c|c|c|}
\hline Sl. No. & Symbol & Treatment Details \\
\hline 1 & $\mathrm{~T}_{1}\left(\mathrm{~F}_{1} \mathrm{~S}_{1}\right)$ & Fertigation with $100 \%$ RDF at monthly interval \\
\hline 2 & $\mathrm{~T}_{2}\left(\mathrm{~F}_{1} \mathrm{~S}_{2}\right)$ & Fertigation with $100 \%$ RDF at bi-monthly interval \\
\hline 3 & $\mathrm{~T}_{3}\left(\mathrm{~F}_{1} \mathrm{~S}_{3}\right)$ & Fertigation with $100 \%$ RDF at quarterly interval \\
\hline 4 & $\mathrm{~T}_{4}\left(\mathrm{~F}_{2} \mathrm{~S}_{1}\right)$ & Fertigation with $80 \%$ RDF at monthly interval \\
\hline 5 & $\mathrm{~T}_{5}\left(\mathrm{~F}_{2} \mathrm{~S}_{2}\right)$ & Fertigation with $80 \%$ RDF at bi-monthly interval \\
\hline 6 & $\mathrm{~T}_{6}\left(\mathrm{~F}_{2} \mathrm{~S}_{3}\right)$ & Fertigation with $80 \%$ RDF at quarterly interval \\
\hline 7 & $\mathrm{~T}_{7}\left(\mathrm{~F}_{3} \mathrm{~S}_{1}\right)$ & Fertigation with $60 \%$ RDF at monthly interval \\
\hline 8 & $\mathrm{~T}_{8}\left(\mathrm{~F}_{3} \mathrm{~S}_{2}\right)$ & Fertigation with $60 \%$ RDF at bi-monthly interval \\
\hline 9 & $\mathrm{~T}_{9}\left(\mathrm{~F}_{3} \mathrm{~S}_{3}\right)$ & Fertigation with $60 \%$ RDF at quarterly interval \\
\hline 10 & $\mathrm{~T}_{10}(\mathrm{Control})$ & Application of $100 \%$ RDF in soil application \\
\hline
\end{tabular}

The existing three year old guava plants were taken for experimentation. There were 4 plants per treatment per replication with spacing of $3 \mathrm{~m} \times 2.5 \mathrm{~m}$. The crop water requirement of each plant was computed at different phases of crop and irrigation was applied through drip irrigation using four online drippers of $4 \mathrm{lph}$ capacity for each plant. The source of irrigation water was tube well. The hydrocyclone filter and disk filter were used for filtration of irrigation water. The ventury injector with manifold was used as fertigation equipment in the trial. The water soluble fertilizers viz. Mono ammonium phosphate (MAP), Sulphate of potash (SOP) and Urea were used for fertigation in the experiment. The soil test based RDF for the experiment was fixed at 300:150:300g $\mathrm{NPK} /$ plant/year and the observations were recorded for MrigBahar (winter season). After initiation of treatments the vegetative parameters were observed and recorded during July to end of December while reproductive parameters were recorded during September to end of December.

The trunk girth was measured with the help of measuring tape at a point marked above $15 \mathrm{~cm}$ from the ground level and annual increment was recorded. Canopy volume and leaf area was calculated as the per the method described by Roose et al., $1986^{[10]}$ and Nava et al., $2014^{[7]}$ respectively, Girth of primary branches and tertiary shoots were recorded using vernier caliper. Number of tertiary shoots per plant, number of leaves per tertiary shoot and number of reproductive shoot per plant were counted from tagged branches in east, west, north and south direction and their average was calculated. The length of tagged tertiary shoots were recorded from the base to the apex with the help of meter scale. Flowering parameters i.e., number of flowers per shoot, fruit set percent and fruit retention percent were recorded by selecting twenty healthy tagged shoots randomly from all directions of the plant and average was calculated.

\section{Results and Discussion Vegetative growth characters}

Plant girth, canopy volume, leaf area, number of tertiary shoots per plant, tertiary shoot length, girth and number of leaves per tertiary shoot were used as indicator to evaluate crop vegetative growth. The maximum increment in plant girth $0.84 \mathrm{~cm}$ was recorded in case of fertigation at $100 \%$ $\mathrm{RDF}$ as compared to minimum value of $0.72 \mathrm{~cm}$ for fertigation at $60 \%$ RDF when averaged over frequency levels. Under the level of fertigation frequency, maximum increment in plant girth of $0.85 \mathrm{~cm}$ was recorded in case of monthly fertigation and minimum value of $0.70 \mathrm{~cm}$ for quarterly fertigation when averaged over fertigation levels. Among the treatment combinations $\mathrm{F}_{1} \mathrm{~S}_{1}$ i.e. fertigation at $100 \% \mathrm{RDF}$ in monthly interval recorded highest increment in plant girth $0.90 \mathrm{~cm}$ followed by fertigation with $80 \%$ RDF at monthly interval i.e., $0.86 \mathrm{~cm}$ and lowest value of $0.62 \mathrm{~cm}$ was observed in case of fertigation at $60 \%$ RDF through quarterly scheduling.

The plant canopy volume exhibited (Table 2) maximum value of $7.76 \mathrm{~m}^{3}$ in fertigation with $100 \% \mathrm{RDF}$ and minimum value of $6.79 \mathrm{~m}^{3}$ for $60 \% \mathrm{RDF}$ when averaged over frequency levels. Similarly monthly fertigation schedule recorded with highest canopy volume $7.80 \mathrm{~m}^{3}$ over bi-monthly and quarterly schedules and averaged over fertigation levels. Further interaction effect of fertigation levels and scheduling interval showed maximum value of $7.79 \mathrm{~m}^{3}$ canopy volume in case of fertigation at $100 \%$ RDF when applied on monthly basis. The total nitrogen and potassium uptake was appreciable higher with increasing nitrogen and potassium rate with more frequent which showed better vegetative growth than with less frequent fertigation. Also the better nutritional environment in the root zone as well as in plant system might have increased the canopy volume. Similar findings were reported by Singh et al. (2009) ${ }^{[12]}$, Kumalwat (2013) ${ }^{[4]}$ and Shirgure et al. (2004) ${ }^{[11]}$.

Maximum leaf area of $49.99 \mathrm{~cm}^{2}$ was recorded in fertigation at $100 \% \mathrm{RDF}$ and minimum value of $46.29 \mathrm{~cm}^{2}$ in fertigation at $60 \% \mathrm{RDF}$ when averaged over frequency of application. The monthly fertigation resulted maximum leaf area of 49.60 $\mathrm{cm}^{2}$ as compared to other fertigation scheduling when averaged over fertigation levels. The interaction effect of fertigation level and frequency of fertigation recorded highest leaf area $50.42 \mathrm{~cm}^{2}$ for $100 \%$ fertigation at monthly interval. Higher leaf area may be due to increased nutrient use efficiency by minimizing the leaching losses coupled with continuous supply of nutrients in frequent split doses during the entire growth period of the guava plants. Similar result was reported by Ramniwas et al. (2012) [9] in guava and Kachwaya and Chandel (2015) ${ }^{[3]}$.

Number of tertiary shoots was recorded maximum of 52.42 due to fertigation at $100 \% \mathrm{RDF}$ and was minimum of 45.32 in fertigation at $60 \%$ RDF when averaged over fertigation frequency. Monthly fertigation schedule reported maximum number of tertiary shoots of 54.48 over quarterly fertigation schedules when averaged over fertigation levels. The interaction effect of fertigation levels and fertigation frequency reported maximum number of tertiary shoots of 58.25 in case of fertigation at $100 \%$ RDF when applied on monthly basis and minimum value of 42.75 in $60 \%$ fertigation when applied on quarterly. Similar observation were made by Mahadevan et al. (2017) ${ }^{[5]}$, Kumalwat (2013) ${ }^{[4]}$ who reported 
maximum number of tertiary shoots under full recommended dose of fertigation in guava. Also increased nitrogen levels caused an increased meristematic activity (Arney, 1951) ${ }^{[1]}$.

The tertiary shoot length, girth and number of leaves per tertiary shoots were significantly maximum in fertigation level of $100 \%$ RDF i.e., $15.27 \mathrm{~cm}, 2.11 \mathrm{~cm}$ and 15.53, respectively as compared to other levels of fertigation when averaged over frequency. The favourable influence of monthly fertigation significantly increased tertiary shoot length, girth and number of leaves per tertiary shoot to maximum of $15.35 \mathrm{~cm}, 2.12 \mathrm{~cm}$ and 15.77 , respectively over other two frequency averaging over fertigation levels. Further, interaction effect of fertigation levels and fertigation frequency showed maximum increase in tertiary shoot length by $16 \mathrm{~cm}$ in case of fertigation at $80 \%$ RDF at monthly interval over other treatment combinations. Whereas, maximum tertiary shoot girth $(2.16 \mathrm{~cm})$ and number of leaves per tertiary shoots (18.00) was observed in $100 \%$ fertigation by monthly fertigation schedule. It may be due to the application major nutrients $\mathrm{N}$ and $\mathrm{K}$ which have specific role on the apical meristematic tissue of main shoot, multiplication and differentiation process which paved the way for sprouting of discs and auxiliary buds. This results corroborate with the finding of Mahdevan et al. (2017) ${ }^{[5]}$ who reported maximum number of tertiary shoots and shoot length in full recommended dose of fertilizer through drip fertigation in guava.

Table 2: Effect of fertigation schedule on vegetative characters of Guava

\begin{tabular}{|c|c|c|c|c|c|c|c|}
\hline Treatments & $\begin{array}{l}\text { Increment in trunk } \\
\text { girth }(\mathrm{cm})\end{array}$ & $\begin{array}{c}\text { Canopy } \\
\text { volume }\left(\mathbf{m}^{3}\right)\end{array}$ & $\begin{array}{c}\text { Leaf area } \\
\left(\mathrm{cm}^{2}\right)\end{array}$ & $\begin{array}{l}\text { Number of tertiary } \\
\text { shoots per plant }\end{array}$ & $\begin{array}{l}\text { Tertiary shoot } \\
\text { length }(\mathrm{cm})\end{array}$ & $\begin{array}{l}\text { Tertiary shoot } \\
\text { girth }(\mathbf{c m})\end{array}$ & $\begin{array}{c}\text { Number of leaves per } \\
\text { tertiary shoot }\end{array}$ \\
\hline$F_{1}$ & 0.84 & 7.76 & 48.99 & 52.42 & 15.27 & 2.11 & 15.53 \\
\hline $\mathrm{F}_{2}$ & 0.79 & 7.42 & 47.68 & 49.98 & 14.94 & 2.07 & 13.97 \\
\hline $\mathrm{F}_{3}$ & 0.72 & 6.79 & 46.29 & 45.32 & 14.02 & 2.01 & 12.77 \\
\hline S. Ed. \pm & 0.04 & 0.05 & 0.25 & 0.15 & 0.30 & 0.03 & 0.34 \\
\hline $\mathrm{CD}(0.05)$ & 0.07 & 0.10 & 0.54 & 0.32 & 0.63 & 0.06 & 0.72 \\
\hline $\mathrm{S}_{1}$ & 0.85 & 7.80 & 49.60 & 54.48 & 15.35 & 2.12 & 15.77 \\
\hline $\mathrm{S}_{2}$ & 0.80 & 7.36 & 48.11 & 48.81 & 14.91 & 2.10 & 14.37 \\
\hline $\mathrm{S}_{3}$ & 0.70 & 6.81 & 45.25 & 44.42 & 13.97 & 1.97 & 12.13 \\
\hline S. Ed. \pm & 0.04 & 0.05 & 0.25 & 0.15 & 0.30 & 0.03 & 0.34 \\
\hline $\mathrm{CD}(0.05)$ & 0.07 & 0.10 & 0.54 & 0.32 & 0.63 & 0.06 & 0.72 \\
\hline $\mathrm{F}_{1} \mathrm{~S}_{1}$ & 0.90 & 7.92 & 50.42 & 58.25 & 15.87 & 2.16 & 18.00 \\
\hline $\mathrm{F}_{1} \mathrm{~S}_{2}$ & 0.83 & 7.79 & 49.14 & 52.50 & 15.89 & 2.11 & 15.30 \\
\hline $\mathrm{F}_{1} \mathrm{~S}_{3}$ & 0.78 & 7.58 & 47.42 & 46.50 & 14.05 & 2.06 & 13.30 \\
\hline $\mathrm{F}_{2} \mathrm{~S}_{1}$ & 0.86 & 7.86 & 49.64 & 56.70 & 16.00 & 2.12 & 15.30 \\
\hline $\mathrm{F}_{2} \mathrm{~S}_{2}$ & 0.81 & 7.82 & 47.77 & 49.23 & 14.86 & 2.09 & 15.00 \\
\hline $\mathrm{F}_{2} \mathrm{~S}_{3}$ & 0.71 & 6.57 & 45.64 & 44.00 & 13.96 & 2.00 & 11.60 \\
\hline $\mathrm{F}_{3} \mathrm{~S}_{1}$ & 0.80 & 7.63 & 48.75 & 48.50 & 14.17 & 2.08 & 14.00 \\
\hline $\mathrm{F}_{3} \mathrm{~S}_{2}$ & 0.75 & 6.47 & 47.42 & 44.70 & 13.98 & 2.09 & 12.80 \\
\hline $\mathrm{F}_{3} \mathrm{~S}_{3}$ & 0.62 & 6.27 & 42.70 & 42.75 & 13.90 & 1.89 & 11.50 \\
\hline Control & 0.60 & 5.20 & 35.96 & 39.25 & 13.51 & 1.86 & 10.60 \\
\hline \multicolumn{8}{|c|}{$\mathrm{CD}(0.05)$} \\
\hline F X S & 0.13 & 0.17 & 0.93 & 0.56 & 1.10 & 0.10 & 1.25 \\
\hline Ctl Vs Rest & 0.09 & 0.12 & 0.69 & 0.42 & 0.82 & 0.07 & 0.93 \\
\hline \multicolumn{8}{|c|}{ S. Ed. \pm} \\
\hline F X S & 0.06 & 0.09 & 0.44 & 0.26 & 0.52 & 0.05 & 0.60 \\
\hline Ctl Vs Rest & 0.04 & 0.07 & 0.33 & 0.20 & 0.39 & 0.03 & 0.44 \\
\hline
\end{tabular}

[F1: 100\%RDF, F2: 80\% RDF, F3: 60\% RDF) through drip fertigation; (S1: Monthly, S2: Bimonthly, S3: quarterly) application of fertilizers; Ctl vs Rest: Control vs Rest treatment combination]

Table 3: Effect of fertigation schedule on reproductive characters of Guava

\begin{tabular}{|c|c|c|c|c|}
\hline Treatments & Number of reproductive shoots per plant & Number of flowers per shoot & Fruit set (\%) & Fruit retention (\%) \\
\hline $\mathrm{F}_{1}$ & 27.50 & 12.03 & 70.64 & 43.84 \\
\hline $\mathrm{F}_{2}$ & 28.25 & 12.61 & 71.14 & 43.90 \\
\hline $\mathrm{F}_{3}$ & 25.25 & 11.11 & 68.77 & 42.52 \\
\hline $\mathrm{S} . \mathrm{Ed} . \pm$ & 1.09 & 0.19 & 0.82 & 0.48 \\
\hline $\mathrm{CD}(0.05)$ & 2.29 & 0.41 & 1.71 & 1.00 \\
\hline $\mathrm{S}_{1}$ & 29.60 & 13.96 & 72.94 & 44.83 \\
\hline $\mathrm{S}_{2}$ & 26.75 & 12.01 & 71.27 & 43.96 \\
\hline $\mathrm{S}_{3}$ & 24.47 & 9.77 & 66.34 & 41.46 \\
\hline $\mathrm{S} . \mathrm{Ed} . \pm$ & 1.09 & 0.19 & 0.82 & 0.48 \\
\hline $\mathrm{CD}(0.05)$ & 2.29 & 0.41 & 1.71 & 1.00 \\
\hline $\mathrm{F}_{1} \mathrm{~S}_{1}$ & 30.50 & 13.76 & 72.81 & 44.91 \\
\hline $\mathrm{F}_{2} \mathrm{~S}_{2}$ & 27.00 & 12.01 & 70.33 & 43.27 \\
\hline $\mathrm{F}_{3} \mathrm{~S}_{3}$ & 25.00 & 10.31 & 68.79 & 43.33 \\
\hline $\mathrm{F}_{2} \mathrm{~S}_{1}$ & 31.50 & 14.81 & 74.49 & 45.60 \\
\hline $\mathrm{F}_{2} \mathrm{~S}_{2}$ & 28.50 & 12.80 & 72.01 & 44.83 \\
\hline $\mathrm{F}_{2} \mathrm{~S}_{3}$ & 24.20 & 10.21 & 66.92 & 41.26 \\
\hline $\mathrm{F}_{3} \mathrm{~S}_{1}$ & 26.80 & 13.30 & 71.51 & 43.97 \\
\hline $\mathrm{F}_{3} \mathrm{~S}_{2}$ & 24.75 & 11.23 & 71.47 & 43.80 \\
\hline
\end{tabular}




\begin{tabular}{|c|c|c|c|c|}
\hline $\mathrm{F}_{3} \mathrm{~S}_{3}$ & 24.20 & 8.80 & 63.32 & 39.80 \\
\hline Control & 25.50 & 8.93 & 63.21 & 37.79 \\
\hline \multicolumn{7}{|c|}{$\mathrm{CD}(0.05)$} \\
\hline F X S & 3.97 & 0.70 & 2.96 & 1.73 \\
\hline Ctl Vs Rest & 2.96 & 0.52 & 2.21 & 1.29 \\
\hline \multicolumn{2}{|c|}{ S. Ed. \pm} & 0.34 & 1.41 & 0.86 \\
\hline F X S & 1.90 & 0.25 & 1.06 & 0.61 \\
\hline Ctl Vs Rest & 1.50 &
\end{tabular}

[F $\mathrm{F}_{1}: 100 \% \mathrm{RDF}, \mathrm{F}_{2}: 80 \%$ RDF, $\left.\mathrm{F}_{3}: 60 \% \mathrm{RDF}\right)$ through drip fertigation; ( $\mathrm{S}_{1}$ : Monthly, $\mathrm{S}_{2}$ : Bimonthly, $\mathrm{S}_{3}$ : quarterly) application of fertilizers; Ctl vs Rest: Control vs Rest treatment combination]

The reproductive parameters (Table-2) in the study i.e. number of reproductive shoots per plant, number of flowers per shoot, fruit set and fruit retention were significantly influenced by the use of different fertigation levels at different frequencies. The data indicated highest number of reproductive shoot $(28.25)$, number of flowers per shoot (12.61), fruit set $(71.14 \%)$ and fruit retention (43.90) at fertigation levels of $80 \%$ RDF which are at par with $100 \%$ RDF. Similarly the number of reproductive shoots (28.25), number of flowers per shoot (11.11), fruit set $(68.77 \%)$ and fruit retention $(42.52 \%)$ were minimum in $60 \%$ RDF when averaged over fertigation frequency.

The fertigation frequency levels recorded significantly higher number of reproductive shoots (29.60), number of flowers per shoots (13.96), fruit set (72.94\%) and fruit retention (44.83\%) in monthly fertigation frequency when averaged over fertigation levels.

The interaction effect of fertigation levels and frequency showed significantly maximum values of reproductive characters of mrigbahar crop at $80 \%$ RDF at monthly interval with number of reproductive shoots (31.50), number of flowers (14.81), fruit set $(79.49 \%)$ and fruit retention (45.60\%) which was closely followed by fertigation at $100 \%$ RDF at monthly interval. The increase in number of flowers might be due to increased number of leaves and leaf area which might have increased accumulation and production of photosynthates that were derived from the sink and produced more flowers. The results are in accordance with the findings of Kumalwat (2013) ${ }^{[4]}$, Nadkarni et al. (2018) ${ }^{[6]}$ and Bhosale et al. (2016). Use of $60 \% \mathrm{RDF}$ through fertigation at quarterly interval resulted in minimum number of reproductive shoots (24.20), number of flowers per shoot (8.80), fruit set $(63.32 \%)$ and fruit retention $(39.80 \%)$ among the interaction combinations. The increase in fruit set and fruit retention might be due to the prolonged availability nutrients in the root zone. The fertilizer dose of $80 \% \mathrm{RDF}$ at monthly interval results in high endogenous ratio of carbohydrate to nitrogen $(\mathrm{C}: \mathrm{N}$ ratio) promotes more flowering, fruit set and fruit retention irrespective of full dose of RDF (100\%) at monthly interval which increased the nitrogen availability (low $\mathrm{C}: \mathrm{N}$ ratio) and promotes the vegetative growth. The findings of fruit set and fruit retention was supported by Kumalwat (2013) ${ }^{[4]}$, Ramniwas et al. (2013) ${ }^{[8]}$ in guava who reported maximum fruit set and fruit retention in $80 \%$ and $75 \% \mathrm{RDF}$ of drip fertigation irrespective of full doze and Nadkarni et al. (2018) [6] in pomegranate. Further on comparison of the control with the interaction treatments was found to superior incase of number of reproductive shoot per plant and number of flowers per shoot while it remain low in fruit set and fruit retention.

\section{Conclusion}

In the present study, $100 \%$ RDF of drip fertigation at monthly interval resulted in maximum vegetative growth but parameters like canopy volume, leaf area, girth of primary branch and tertiary shoots remain at par with $80 \%$ RDF when applied over monthly basis. Further all of the reproductive parameters recorded maximum values at $80 \%$ RDF at monthly interval and saves $20 \%$ of fertilizers. Thus, from the above study it is concluded that $80 \%$ RDF of drip fertigation at monthly interval is economically ideal.

\section{References}

1. Arney SE. Some effects of nitrogen nutrients on the morphological and anatomy of narrow stem kale, Annals of Applied Biology. 1951; 39:226-76.

2. Bhosale PR, Waghmore GM, Suman M. Effect of fertigation period on growth, yield \& nutrient content of strawberry (Fragaria ananassa) var. winter dawn under substrate at Marathwada Agriculture University, The bioscan. 2016; 11(4):2631-2635.

3. Kachwaya DK, Chandel JS. Effect of fertigation on growth, yield, fruit quality and leaf nutrients content of strawberry (Fragaria $\times$ ananassa) $\mathrm{cv}$ Chandler. Indian Journal of Agricultural Sciences. 2015; 85(10):13191323.

4. Kumawat KL. Assessment of Spacing and Fertigation Schedule of Guava (Psidium guajava L.) under Ultra High Density Planting System. Thesis, Doctoral of Philosophy (Horticulture), Rajasthan College of Agriculture Maharana Pratap University of Agriculture and Technology, Udaipur (India), 2013.

5. Mahadevan A, Kumar S, Swaminathan V, Gurusamy A, Sivakumar T. Effect of crop regulation \&fertigation on quality characters of guava (Psidium guajava) cv. Sardar, International Journal of current microbiology and applied sciences. 2017; 6(11):2137-2141.

6. Nadkarni BH, Bhalekar MN, Durgude MN. Effect of nutrient scheduling on flowering, fruit set and yield of pomegranate (Punica granatum L.) Cv. Phule Bhagwa Super. International Journal of Chemical Studies. 2018; 6:6.

7. Nava AD, Victor A, Hernandez G, James MV, Castro EL, Alvarez DV et al. Growth kinetics of vegetative and reproductive organs of guava (Psidium guajava L.) in Iguala Gurrero, Mexico. Agricultural Sciences. 2014; 5:1468-1475.

8. Ramniwas, Kaushik RA, Pareek S, Sarolia DK, Singh V. Effect of Drip Fertigation Scheduling on Fertilizer Use Efficiency, Leaf Nutrient Status, Yield and Quality of 'Shweta' Guava (Psidium guajava L.) under Meadow Orcharding, The National Academy of Sciences. 2013; 36(5):483-488.

9. Ramniwas, Kaushik RA, Sarolia DK. Response of irrigation and fertigation scheduling on flowering, physiological parameters and fruit yield of guava (Psidium guajava L.) under high density planting, Annals of Agricultural Research. New Series. 2012; 33(3):115120. 
10. Roose ML, Cole DA, Atkin D, Kuper RS. Yield and tree size of four citrus cultivars on 21 rootstocks in California. J American Society of Horticultural Science. 1986; 114:135-140.

11. Shirgure PS, Srivastava AK, Singh S. Growth, yield and quality of Nagpur mandarin Citrus reticulate in relation to irrigation and fertigation. Indian Journal of Agricultural Sciences. 2004; 71:547-550.

12. Singh SK, Singh CP. Response of fertigation and plastic mulch on growth characteristics of young "Dashehari" mango. Indian Journal of Horticulture. 2009; 66(3):390392. 